ENTREPRENEURSHIP AND SUSTAINABILITY ISSUES

ISSN 2345-0282 (online) http://jssidoi.org/jesi/ 2021 Volume 9 Number 1 (September)

http://doi.org/10.9770/jesi.2021.9.1(34)

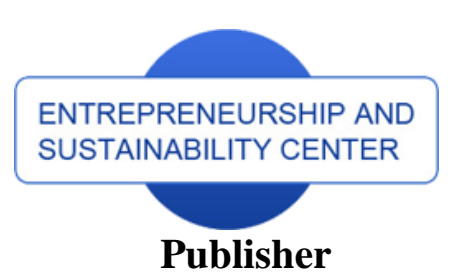

$\underline{\text { http://jssidoi.org/esc/home }}$

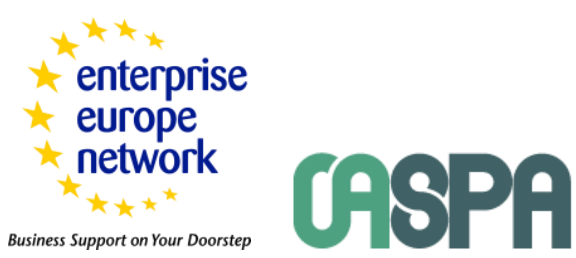

Business Support on Your Doorstep

\title{
WEBSITE QUALITY FACTOR AS A MULTIDIMENSIONAL CONSTRUCT AND ITS IMPACT ON THE USE OF E-BANKING*
}

\author{
Radovan Bacik ${ }^{1}$, Beata Gavurova ${ }^{2}$ Igor Fedorko $^{3}$, Richard Fedorko ${ }^{4}$ \\ 1,3,4 University of Prešov, Faculty of Management, Konštantínova 16, 08001 Prešov, Slovakia \\ ${ }^{2}$ Technical University of Košice, Faculty of Mining, Ecology, Process Control and Geotechnologies, Letná 9 , \\ 04200 Košice, Slovakia \\ E-mails: ${ }^{1}$ radovan.bacik@unipo.sk; ${ }^{2}$ beata.gavurova@tuke.sk; ${ }^{3}$ igor.fedorko@unipo.sk; ${ }^{4}$ richard.fedorko@unipo.sk
}

Received 12 February 2021; accepted 25 May 2021; published 30 September 2021

\begin{abstract}
The aim of this paper is to determine the significance of the impact of website quality on the expected performance and the actual use of e-banking. The aim of this paper is to create a model that identifies the impact of website quality on the use of electronic banking. With Unified Theory of Acceptance and Use of Technology (UTAUT) and use of technology as a theoretical basis, this paper identifies specific features of websites and their impact on the use of internet banking by tourists in destinations. In general, the results of our research show that the perceived quality of the website is a multi-dimensional concept. The quality of the website has an indirect impact on the behavior of the user, which is expressed by the frequency of using internet banking. This indirect effect is mediated by the expected performance factor.
\end{abstract}

Keywords: e-banking usage; website quality factors; consumer behavior; UTAUT; website usage

Reference to this paper should be made as follows: Fedorko, I., Fedorko, R., Gavurova, B., Bacik, R. 2021. Website quality factor as a multidimensional construct and its impact on the use of e-banking. Entrepreneurship and Sustainability Issues, 9(1), 542-557. http://doi.org/10.9770/jesi.2021.9.1(34)

JEL Classifications: M12

Additional disciplines Personnel Management

\footnotetext{
* This article is one of the partial outputs under the scientific research grant VEGA 1/0694/20 - Relational marketing research - the perception of e-commerce aspects and its impact on purchasing behaviour and consumer preferences and VEGA 1/0609/19 - Research on the development of electronic and mobile commerce in the aspect of the impact of modern technologies and mobile communication platforms on consumer behaviour and consumer preferences and 1/0807/19 - Research on the determinants of trading behavior and marketing effects in the area of neuromarketing and the relation to neuro-linguistic programming
} 


\section{ENTREPRENEURSHIP AND SUSTAINABILITY ISSUES}

ISSN 2345-0282 (online) http://jssidoi.org/jesi/

2021 Volume 9 Number 1 (September)

http://doi.org/10.9770/jesi.2021.9.1(34)

\section{Introduction}

Continuous advances in online technologies and related applications enable consumers to interact with businesses and institutions in several ways. More and more organizations are investing heavily in electronic customer centric solutions and technologies to increase their online market share (Małkowska, Urbaniec \& Kosała, 2021). As Vila and Kuster (2011) observe in their study, companies spend a significant amount of this effort on improving the visual and design of their websites and on enhancing the quality of their customers' interactive experiences. Further research in this area usually focuses on exploring the relationship between website design and consumer behavior (Kwon, Kim \& Lee 2002; Moss, Gunn \& Heller 2006).

\section{Starting points for technology acceptance models - theoretical background}

In recent years, the internet has been steadily expanding and now offers a number of web-based applications that provide organizations with a new way of reaching and retaining consumers by offering new services and products (Tan, Teo 2000). In the interests of both parties (organizations and consumers), it is very important to monitor and analyze the real perception and the main reasons for consumers' willingness to adapt to these technologies (Lee 2009; Streimikiene \& Ahmed, 2021; Gorączkowska, 2020).

Despite the significant importance of website design, previous research does not provide consistent information about which website attributes affect user perception. Thongpapanl and Ashraf (2011) report in their publications that studies report conflicting results related to the amount of information that websites should contain to reduce consumer risk perception and enable informed purchasing decisions. Gounaris, Koritos \& Vassilikopolou (2010), like previous authors, emphasize the importance of the atmosphere in the process of conducting online transactions. Further research in this area (Venkatesh, Morris \& Davis, 2003; Andrews, Bianchi 2013, Cortinas, Chocarro \& Villanueva, 2010, Toufaily, Ricard \& Perrine, 2013; Al Qeisi, Dennis, Alamanos, Jayawardhena 2014) examines the way individual elements website and the quality of interaction experience affect consumer behavior in connection with the Unification Theory of Acceptance and Use of Technology - UTAUT).

Consumers in the context of banking services have a choice of different channels of transaction execution, such as: personal computer, mobile phone, tablet, or face-to-face banking. However, most users tend to use more than one channel, which may depend on the type of transaction, e.g. face-to-face channel for banking with high transaction engagement (loans) and use of online channels for low transaction engagement (account status) (Cortiñas, Chocarro \& Villanueva, 2010). Banks operate in a competitive environment and, to differentiate their online activities, they tend to emphasize different characteristics of website design, their utilitarian (productrelated information, navigation) or hedonic (aesthetics) aspects, to facilitate the transaction experience for consumers (Korzeb \& Niedziółka, 2020; Ahmed, Romeika, Kauliene, Streimikis \& Dapkus, 2020) and meet the needs of different consumer segments (Floh, Zauner, Koller \& Rush, 2014).

Internet banking has proven to be one of the most profitable e-commerce platforms (Lee 2009). Most banking institutions have implemented Internet banking systems in an effort to reduce costs while increasing the level of service to customers (Xue, Hitt \&Chen, 2011). Despite the many potential benefits that electronic banking offers to consumers, its adaptation has been limited, and in many cases has not met expectations (Bernardelli, Korzeb \& Niedziółka, 2021).

While previous research focuses on factors that influence end-user adoption of information technology, there is limited empirical evidence that would capture the positive (success factors) and negative (resistance factors) that drive consumers in adapting Internet banking (Lee 2009). Following the premise that Internet banking services are perceived as risky in relation to traditional banking services (Cunningham, Gerlach, Harper \& Young, 2005), 


\section{ENTREPRENEURSHIP AND SUSTAINABILITY ISSUES}

ISSN 2345-0282 (online) http://jssidoi.org/jesi/ 2021 Volume 9 Number 1 (September) http://doi.org/10.9770/jesi.2021.9.1(34)

a study by Martins, Oliveira \& Popovič (2014) provides an assessment of the perceived risk factor. Based on perceived risk theory, the study combines specific aspects of perceived risk (Featherman \& Pavlou, 2003), namely performance, finance, time, psychological aspects, social aspects, privacy and overall risk - with a Unified Theory of Acceptance and Use of Technology (UTAUT) for designing an integrated model to explain the consumer intent for adapting and using internet banking. Research by these authors links existing and empirically proven theoretical models with the perceived risk factor (which is an important construct) for testing adaptation of Internet banking. The study helps banking institutions understand the determinants that affect users and develop the right formal measures to attract consumers to use the services. In addition, it is in the interest of both parties to redirect their communication from bank branches to online channels, pursuing higher productivity and cost reduction.

Websites and internet technologies are now well established and reliable elements of marketing communication, however, it is important to know what factors affect the success of a website. Previous research focused on identifying company-controlled design factors of websites that could increase online sales and result in customer satisfaction, confidence and reduce perceived risk. SME managers should be able to develop websites that Internet users visit, although not all visits will lead to purchases and conversions (Vila \& Kuster 2011).

The study by Vilu \& Kuster (2011) is based on the foundations of information systems theory, marketing and psychology in an integrated theoretical framework of online consumer behavior. Their goal was to create a tool capable of measuring various desired effects of a well-designed website in terms of satisfaction, online trust, perceived risk and intent to purchase. The tool was designed to provide a one-dimensional measurement of welldesigned websites. The advantage of this model is the common measure of different items for the same size or construct.

\section{Model and hypothesis development}

The aim of this paper is to determine the significance of the impact of website quality on the expected performance and the actual use of e-banking. The aim of this paper is to create a model that identifies the impact of website quality on the use of electronic banking. This model is intended to explain how the elements that we present as factors of website quality affect user behavior in the context of using electronic banking. With UTAUT and use of technology as a theoretical basis, this paper identifies specific features of websites and their impact on the use of internet banking.

The UTAUT model defines facilitation conditions as a construct that reflects the perception of a person's control over their behavior (Venkatesh, Brown, Maruping \& Bala, 2008). Al-Queisi et al. (2014) support the view that the quality of website design is related to the importance of facilitating terms. The research deals with the relationships between web elements and their impact on user intentions (Bauer, Hammerschmidt \& Falk, 2005). Dennis, Merrilees, Jayawardhena \& Wright (2009) demonstrate that website attributes affect online behavior. Aladwani \& Palvia (2002) explored key characteristics of website quality from the user perspective. The current research adopts their definitions of perceived website quality as a user rating of individual sections of the website that meet the needs of visitors and reflect the overall quality of the website. Aladwani (2006) proposed a model that examines the impact of the four sub-dimensions of a website on consumer attitudes and purchasing intentions. The first component is the technical dimension, which covers the characteristics of the website, such as security, ease of navigation, search options, website availability, link validity, personalization, website load time, interactivity and easy access. The second component is total content, which includes characteristics such as content usefulness, completeness, clarity, consistency and accuracy. The third component is specific content that carries features such as contact information, general information about the institution, details of products and services, consumer policy and customer support. The last component is the overall look that includes features 


\section{ENTREPRENEURSHIP AND SUSTAINABILITY ISSUES}

ISSN 2345-0282 (online) http://jssidoi.org/jesi/

2021 Volume 9 Number 1 (September)

http://doi.org/10.9770/jesi.2021.9.1(34)

such as attractiveness, organization, correct font, color and media usage. We therefore formulate the following hypotheses:

H1. Website quality has a significant impact on expected performance.

$\mathrm{H} 2$. Website quality has a significant impact on the use of internet banking.

\section{Materials and Methods}

For research purposes, we focus on EU-based banking institutions and the tools they provide in an online environment that facilitate work with their products and electronic banking itself. Based on the stated main objective and sub-objectives, we identified the following research problems. Is there a statistically significant link between website quality (Aladwani, 2006) and expected performance? Is there a statistically significant link between the quality of the website (Aladwani, 2006) and the use of internet banking?

The primary data for the study was collected through a questionnaire survey. The respondents were users of internet banking and, in terms of demographic characteristics, copied a sample of common internet banking users across EU countries (Yousafzai \& Yani-de-Soriano 2012; Al-Qeisi, Dennis, Alamanos \& Jayawardhena, 2014). A pilot survey was carried out on a sample of 41 respondents, university colleagues to verify the clarity of questionnaire items. By means of the test-retest method and repeated use of the research tool, we verified the reliability of the research file. The survey sample consists of $279(61.45 \%)$ men and $175(38.55 \%)$ women, the majority of the respondents reported a higher level of education (bachelor's degree or higher) and 158 (34.80\%) respondents were in the age from 19 to 29 years. In the research we used Confirmatory Factor Analysis, multiple linear regression analysis - for the purpose of interpreting associations between quantitative variables and Structural Equation Modeling.

\section{Results}

The questionnaire items regarding the performance expectancy factor were addressed through items aimed at perceived usefulness, easy completion of tasks, efficiency and improvement of the quality of performance of banking tasks via online banking. Together, the other four groups of items form separate factors, which we will later combine into a single whole, and through it we will express one coherent factor, which we will call the quality of the website. The first partial factor of this whole is the Technical Quality (TQ), which expresses and describes the technical aspects and characteristics of the website such as security, ease of navigation, search tools, website availability, link validity, personalization or customization, interactivity and ease of access (Aladwani, 2006). The items we used in the questionnaire were as follows (TQ 1-7). My bank's internet banking:

- TQ 1: Looks safe for financial transactions;

- TQ 2: Is easy to navigate;

- TQ 3: Has an adequate search system;

- TQ 4: Has functional links;

- TQ 5: Has many interactive features;

- TQ 6: Is easy to access;

- TQ 7: Loads quickly.

The results indicate positive evaluations of individual statements, with respondents most unambiguous in the answers related to easy accessibility (45.59\%) and fast loading of internet banking websites (40.09\%). It is interesting to observe the respondents' neutral attitudes regarding the number of interactive elements on the website $(25.11 \%)$, which can be explained by the fact that respondents may perceive these elements of interactivity more subjectively (see table 1 and . 
ISSN 2345-0282 (online) http://jssidoi.org/jesi/ 2021 Volume 9 Number 1 (September) http://doi.org/10.9770/jesi.2021.9.1(34)

Table 1. An overview of results for the technical quality of the website

\begin{tabular}{|c|c|c|c|c|c|c|c|}
\hline \multirow[t]{3}{*}{ Factor } & 1 & 2 & 3 & 4 & 5 & 6 & 7 \\
\hline & $(\%)$ & $(\%)$ & $(\%)$ & $(\%)$ & $(\%)$ & $(\%)$ & $(\%)$ \\
\hline & $\mathrm{N}$ & $\mathrm{N}$ & $\mathrm{N}$ & $\mathrm{N}$ & $\mathrm{N}$ & $\mathrm{N}$ & $\mathrm{N}$ \\
\hline \multirow[t]{2}{*}{ TQ 1} & 2.42 & 2.64 & 4.85 & 10.57 & 15.64 & 28.19 & 35.68 \\
\hline & 11 & 12 & 22 & 48 & 71 & 128 & 162 \\
\hline \multirow[t]{2}{*}{ TQ 2} & 1.98 & 3.30 & 3.74 & 7.27 & 21.81 & 30.40 & 31.50 \\
\hline & 9 & 15 & 17 & 33 & 99 & 138 & 143 \\
\hline \multirow[t]{2}{*}{ TQ 3} & 1.54 & 3.52 & 4.41 & 13.66 & 22.69 & 28.85 & 25.33 \\
\hline & 7 & 16 & 20 & 62 & 103 & 131 & 115 \\
\hline \multirow[t]{2}{*}{ TQ 4} & 1.54 & 1.98 & 5.29 & 15.42 & 17.62 & 25.99 & 32.16 \\
\hline & 7 & 9 & 24 & 70 & 80 & 118 & 146 \\
\hline \multirow[t]{2}{*}{ TQ 5} & 1.32 & 4.19 & 6.83 & 25.11 & 21.59 & 21.15 & 19.16 \\
\hline & 6 & 19 & 31 & 117 & 98 & 96 & 87 \\
\hline \multirow[t]{2}{*}{ TQ 6} & 1.54 & 2.42 & 3.08 & 3.08 & 16.08 & 28.19 & 45.59 \\
\hline & 7 & 11 & 14 & 14 & 73 & 128 & 207 \\
\hline \multirow[t]{2}{*}{ TQ 7} & 2.64 & 1.76 & 7.71 & 4.63 & 15.42 & 27.75 & 40.09 \\
\hline & 12 & 8 & 35 & 21 & 70 & 126 & 182 \\
\hline
\end{tabular}

Legend: 1 - Totally disagree; 3 - Neutral stance; 7 - Totally agree Source: own elaboration

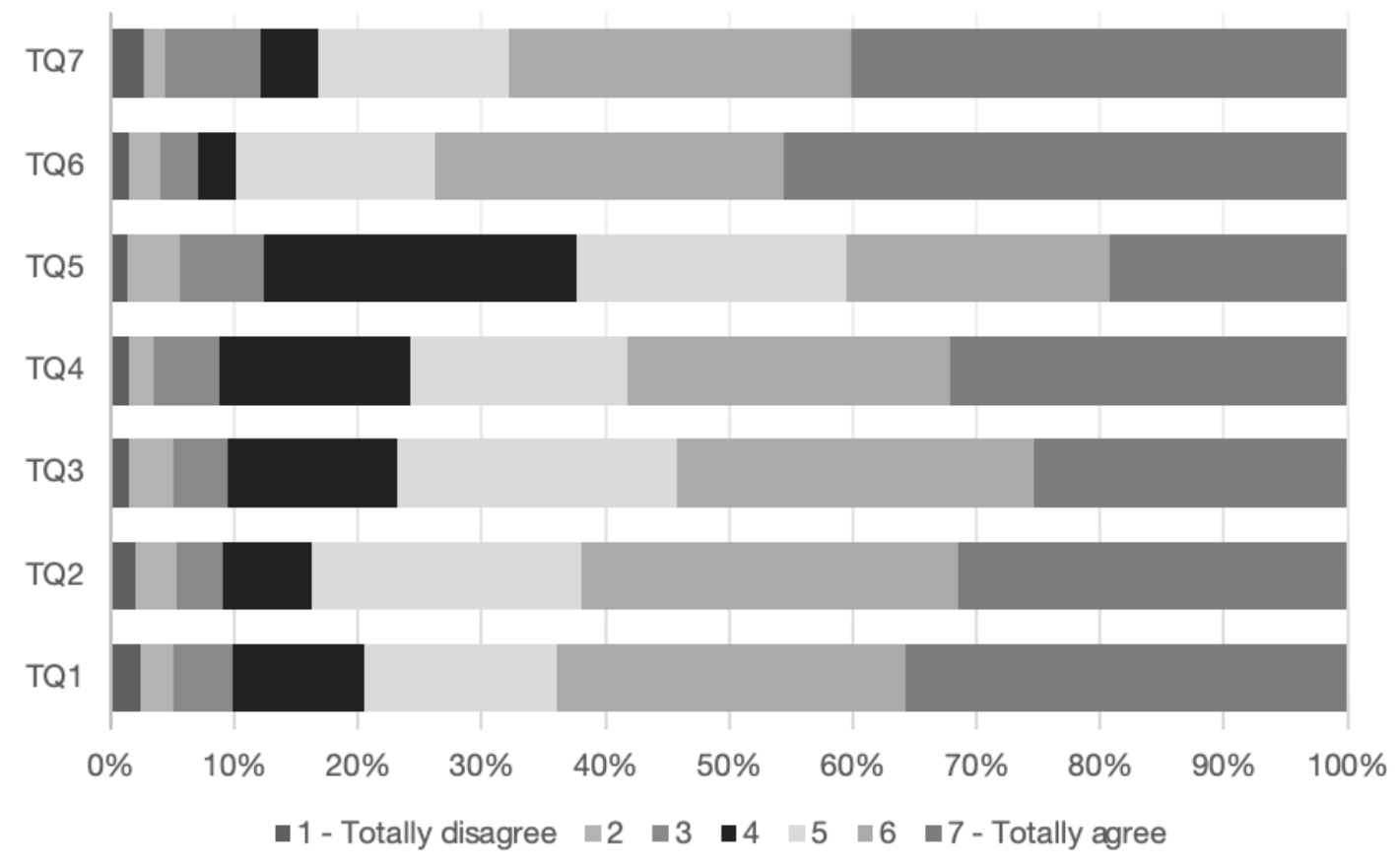

Figure 1. An overview of results for the technical quality of the website Source: own elaboration

GQ - General Content Quality reflects the characteristics of a banking institution's website, such as its usefulness, completeness, clarity, timeliness, consistency and accuracy (Aladwani 2006). The items we used in the survey were as follows (GQ 1-6). For the completeness and understanding of the respondent, we have added additional 
information in parentheses to the individual attributes of the overall quality of the banking website content. My bank's online banking content is:

- GQ 1: Helpful (site content is helpful);

- GQ 2: Complete (I can find all important information on the site);

- GQ 3: Clear (page content is understandable to me);

- GQ 4: Current (I can find up-to-date information on the page);

- GQ 5: Descriptive (I can find what I am looking for on the page);

- GQ 6: Accurate (this page shows correct and truthful information).

The results of the items concerning the overall quality factor of the internet banking website content are positive. Most respondents (42.73\%) responded positively to the item regarding the up-to-date nature of the website content (GQ 4). Positive responses were also recorded to other items and positive answers exceeded $80 \%$ in all cases. Therefore, we can state that the overall quality of the website content of banks is perceived positively by the respondents and that users find useful, complete, clear, up-to-date, concise and accurate content on the website (see table 2 and figure 2).

Table 2. An overview of results for the technical quality of the website

\begin{tabular}{|c|c|c|c|c|c|c|c|}
\hline \multirow[t]{3}{*}{ Factor } & 1 & 2 & 3 & 4 & 5 & 6 & 7 \\
\hline & $(\%)$ & $(\%)$ & $(\%)$ & $(\%)$ & $(\%)$ & $(\%)$ & $(\%)$ \\
\hline & $\mathrm{N}$ & $\mathrm{N}$ & $\mathrm{N}$ & $\mathrm{N}$ & $\mathrm{N}$ & $\mathrm{N}$ & $\mathrm{N}$ \\
\hline \multirow[t]{2}{*}{ GQ 1} & 1.53 & 2.42 & 3.96 & 5.95 & 24.45 & 26.87 & 34.80 \\
\hline & 7 & 11 & 18 & 27 & 111 & 122 & 158 \\
\hline \multirow[t]{2}{*}{ GQ 2} & 1.32 & 3.08 & 5.95 & 8.59 & 21.59 & 29.52 & 29.96 \\
\hline & 6 & 14 & 27 & 39 & 98 & 134 & 136 \\
\hline \multirow[t]{2}{*}{ GQ 3} & 1.76 & 1.98 & 6.17 & 7.05 & 18.94 & 32.60 & 31.72 \\
\hline & 8 & 9 & 28 & 31 & 86 & 148 & 144 \\
\hline \multirow[t]{2}{*}{ GQ 4} & 1.98 & 0.88 & 6.17 & 7.93 & 13.88 & 28.19 & 42.73 \\
\hline & 9 & 4 & 20 & 36 & 63 & 128 & 194 \\
\hline \multirow[t]{2}{*}{ GQ 5} & 1.98 & 2.20 & 4.63 & 6.61 & 22.91 & 31.06 & 30.62 \\
\hline & 9 & 10 & 21 & 30 & 104 & 141 & 139 \\
\hline \multirow[t]{2}{*}{ GQ 6} & 1.10 & 2.20 & 4.85 & 9.69 & 14.98 & 28.63 & 38.55 \\
\hline & 5 & 10 & 22 & 44 & 68 & 130 & 175 \\
\hline
\end{tabular}

Legend: 1 - Totally disagree; 3 - Neutral stance; 7 - Totally agree 


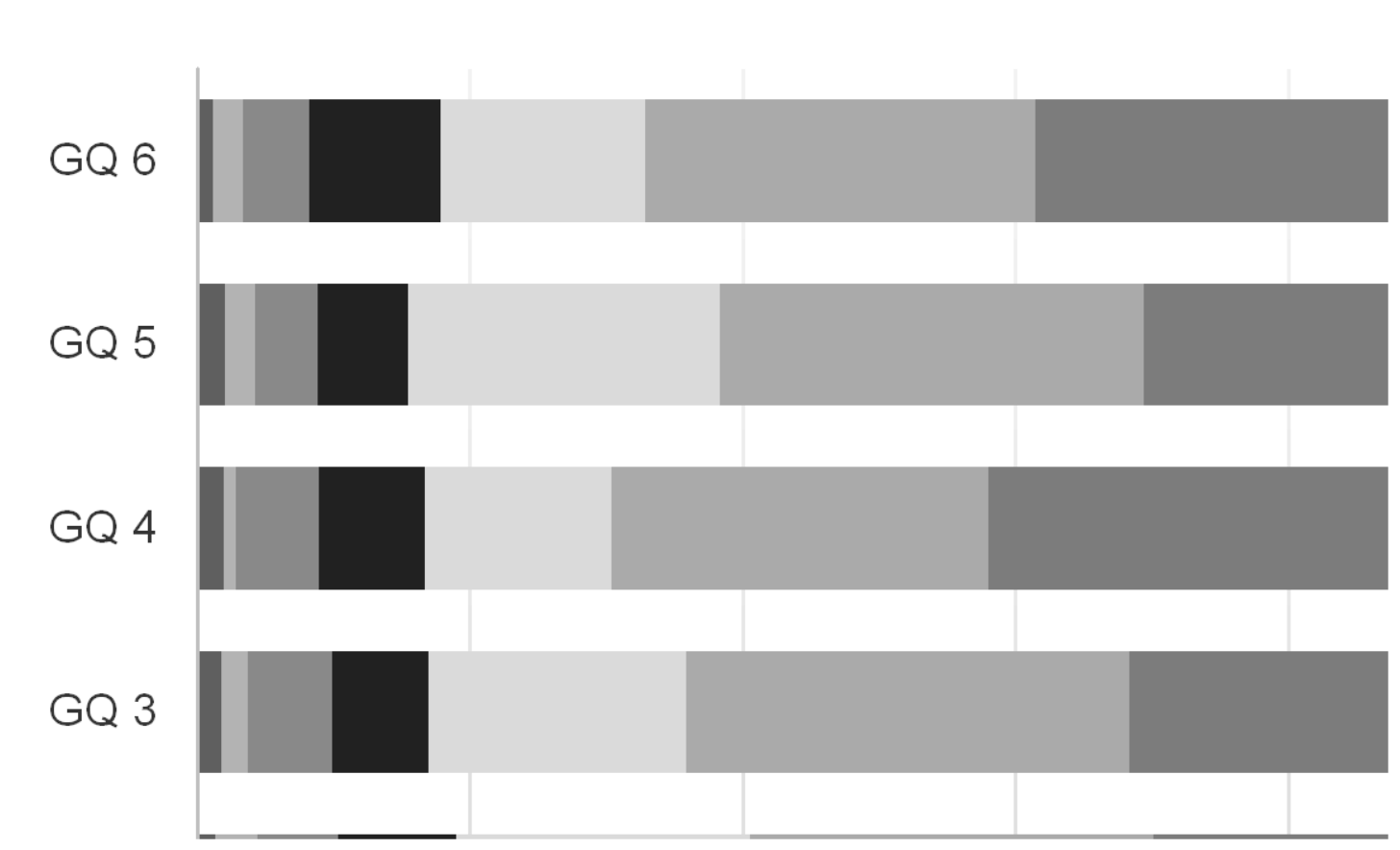

Figure 2. An overview of results for total content quality factor

Another factor is the quality of special content (SQ - Special Content Quality), which means specific content on a website, such as contact information, general bank information, detailed information about the bank's products and services, and customer support information (Aladwani, 2006). The items we used in the survey were as follows (SQ 1-5). In the internet banking website of my bank I can find:

- SQ 1: Corresponding contact information;

- SQ 2: General bank information;

- SQ 3: Details of the Bank's products and services;

- SQ 4: Customer policy information;

- SQ 5: Information in relation to customer services.

As the results shown in the above table indicate, a higher proportion of neutral answers can be observed in items concerning customer policy information $(31.50 \%)$ and customer service information $(24.67 \%)$. The answers are positive, with a majority of respondents expressing one of the different degrees of agreement with the statements, with most respondents responding positively to items regarding contact (44.71\%) and general (44.27\%) information (table 3). 
Table 3. An overview of results for the technical quality of the website

\begin{tabular}{|c|c|c|c|c|c|c|c|}
\hline \multirow[t]{3}{*}{ Factor } & 1 & 2 & 3 & 4 & 5 & 6 & 7 \\
\hline & $(\%)$ & $(\%)$ & $(\%)$ & $(\%)$ & $(\%)$ & $(\%)$ & $(\%)$ \\
\hline & $\mathrm{N}$ & $\mathrm{N}$ & $\mathrm{N}$ & $\mathrm{N}$ & $\mathrm{N}$ & $\mathrm{N}$ & $\mathrm{N}$ \\
\hline \multirow[t]{2}{*}{ SQ 1} & 1.10 & 2.20 & 3.08 & 12.56 & 15.20 & 21.15 & 44.71 \\
\hline & 5 & 10 & 14 & 57 & 69 & 96 & 203 \\
\hline \multirow[t]{2}{*}{ SQ 2} & 0.66 & 2.42 & 3.74 & 10.79 & 15.86 & 22.25 & 44.27 \\
\hline & 3 & 11 & 17 & 49 & 72 & 101 & 201 \\
\hline \multirow[t]{2}{*}{ SQ 3} & 0.88 & 3.74 & 4.19 & 12.11 & 15.64 & 26.43 & 37.00 \\
\hline & 4 & 17 & 19 & 55 & 71 & 120 & 168 \\
\hline \multirow[t]{2}{*}{ SQ 4} & 1.54 & 4.63 & 3.52 & 31.50 & 19.82 & 18.50 & 20.48 \\
\hline & 7 & 21 & 16 & 143 & 90 & 84 & 93 \\
\hline \multirow[t]{2}{*}{ SQ 5} & 0.88 & 4.19 & 3.30 & 24.67 & 18.94 & 22.91 & 25.11 \\
\hline & 4 & 19 & 15 & 112 & 86 & 104 & 114 \\
\hline
\end{tabular}

Legend: 1 - Totally disagree; 3 - Neutral stance; 7 - Totally agree

Source: own elaboration

The last factor that is connected with the website quality is the AQ - Appearance Quality. This factor describes the appearance quality attributes of a website, such as attractiveness, orderly manner of content display, proper use of web fonts, colors and multimedia (Aladwani, 2006). The items we used in the survey were as follows (AQ 1-5). My bank's internet banking:

- AQ 1: Looks attractive;

- AQ 2: Looks organized;

- AQ 3: Easy to read;

- AQ 4: Use appropriate colors;

- AQ 5: Uses appropriate multimedia content.

Respondents responded most positively to the suitability of used colors (43.61\%) and the ease of reading the website (37.22\%). The respondents evaluated most negatively the attractiveness of the appearance of the website $(12,99 \%$ in total) and expressed a neutral opinion on the question of the suitability of using multimedia content $(15,64 \%)$ (see table 4$)$.

Table 4. An overview of results for the technical quality of the website

\begin{tabular}{|c|c|c|c|c|c|c|c|}
\hline \multirow[t]{3}{*}{ Factor } & 1 & 2 & 3 & 4 & 5 & 6 & 7 \\
\hline & $(\%)$ & $(\%)$ & $(\%)$ & $(\%)$ & $(\%)$ & $(\%)$ & $(\%)$ \\
\hline & $\mathrm{N}$ & $\mathrm{N}$ & $\mathrm{N}$ & $\mathrm{N}$ & $\mathrm{N}$ & $\mathrm{N}$ & $\mathrm{N}$ \\
\hline \multirow[t]{2}{*}{ AQ 1} & 1.32 & 2.86 & 8.81 & 8.15 & 26.87 & 22.25 & 29.74 \\
\hline & 6 & 13 & 40 & 37 & 122 & 101 & 135 \\
\hline \multirow[t]{2}{*}{ AQ 2} & 1.32 & 1.10 & 6.83 & 4.63 & 23.13 & 28.85 & 34.14 \\
\hline & 6 & 5 & 31 & 21 & 105 & 131 & 155 \\
\hline \multirow[t]{2}{*}{ AQ 3} & 1.10 & 2.42 & 5.51 & 4.63 & 19.38 & 29.74 & 37.22 \\
\hline & 5 & 11 & 25 & 21 & 88 & 135 & 169 \\
\hline \multirow[t]{2}{*}{ AQ 4} & 1.32 & 2.42 & 4.19 & 6.17 & 15.64 & 26.65 & 43.61 \\
\hline & 6 & 11 & 19 & 28 & 71 & 121 & 198 \\
\hline \multirow[t]{2}{*}{ AQ 5} & 1.54 & 2.86 & 3.74 & 15.64 & 18.06 & 25.11 & 33.04 \\
\hline & 7 & 13 & 17 & 71 & 82 & 114 & 150 \\
\hline
\end{tabular}

Legend: 1 - Totally disagree; 3 - Neutral stance; 7 - Totally agree

Source: own elaboration

The last item of the questionnaire survey dealt with the frequency of using electronic banking in its various forms by the respondent. The range of responses corresponds to the methodology of previous research in this field (AlQeisi et al. 2014). We asked respondents how often they use internet banking. As can be seen from the results, 
most respondents use electronic banking at a frequency of once a week (28.19\%) and once a month $(23.35 \%)$. On the other hand, respondents least frequently use electronic banking at intervals of six months $(2.86 \%)$, once a year (3.30\%), and 10 respondents $(2.20 \%)$ do not use electronic banking at all. We have included these respondents in the results of our research even though they are not currently using electronic banking but have used it at least once in the past.

\section{Validation of website quality factor}

The first part of the analysis focuses on the validation of the website quality, which consists of four sub-factors, resulting in the web design quality factor as a higher-level structure. Before incorporating the perceived website quality factor into a multidimensional construct, this paper addressed and tested the four sub-dimensions of website quality through direct links to user behavior by a one-stage analysis model methodology. Therefore, we decided to address the website quality factor as a multidimensional construct. In the first step, we tested the Web Quality Factor (WQ) through confirmatory factor analysis using four factors: technical quality, overall content quality, quality of special content, website quality (Al-Qeisi et al. 2014). Confirmatory Factor Analysis (using R Studio software) was performed several times, with the original model reaching the values that can be seen in the tables 5,6 and 7 below.

Table 5. Overview of CFA results for the WQ factor

\begin{tabular}{|c|c|c|c|}
\hline $\begin{array}{c}\chi^{2} \\
\text { (chi square) }\end{array}$ & $\begin{array}{c}\text { df } \\
\text { (degrees of freedom) }\end{array}$ & $\begin{array}{c}\text { CFI } \\
\text { (comparative fit index) }\end{array}$ & $\begin{array}{c}\text { RMSEA } \\
\text { (Root Mean Square Error of } \\
\text { Approximation) }\end{array}$ \\
\hline 838,595 & 224 & 0,937 & 0,078 \\
\hline
\end{tabular}

Source: own elaboration 
Table 6. CFA for WQ factor - Overview of latent variable results

\begin{tabular}{|c|c|c|c|}
\hline & Estimate & Std. Error & Z-value \\
\hline \multicolumn{4}{|c|}{ TQ (Technical quality) } \\
\hline TQ1 & 1 & & \\
\hline TQ2 & 1.136 & 0.061 & 18.578 \\
\hline TQ3 & 1.126 & 0.061 & 18.477 \\
\hline TQ4 & 1.031 & 0.062 & 16.635 \\
\hline TQ5 & 0.944 & 0.063 & 15.039 \\
\hline TQ6 & 1.074 & 0.057 & 18.710 \\
\hline TQ7 & 1.072 & 0.065 & 16.368 \\
\hline \multicolumn{4}{|c|}{ GQ (General content quality) } \\
\hline GQ1 & 1 & & \\
\hline GQ2 & 1.073 & 0.044 & 24.151 \\
\hline GQ3 & 1.082 & 0.043 & 25.039 \\
\hline GQ4 & 1.049 & 0.043 & 24.401 \\
\hline GQ5 & 1.060 & 0.043 & 24.604 \\
\hline GQ6 & 1.040 & 0.044 & 23.708 \\
\hline \multicolumn{4}{|c|}{ SQ (Special content quality) } \\
\hline SQ1 & 1 & & \\
\hline SQ2 & 1.024 & 0.053 & 19.378 \\
\hline SQ3 & 1.114 & 0.055 & 20.319 \\
\hline SQ4 & 1.081 & 0.056 & 19.302 \\
\hline SQ5 & 1.106 & 0.055 & 20.268 \\
\hline \multicolumn{4}{|c|}{ AQ (Appearance Quality) } \\
\hline AQ1 & 1 & & \\
\hline AQ2 & 1.029 & 0.044 & 23.246 \\
\hline AQ3 & 1.002 & 0.046 & 21.802 \\
\hline AQ4 & 0.956 & 0.048 & 19.913 \\
\hline AQ5 & 1.006 & 0.050 & 20.074 \\
\hline
\end{tabular}

Table 7. CFA for factor WQ - Overview of results of covariance and variance values (variance)

\begin{tabular}{|c|c|c|c|c|c|}
\hline & Estimate & Std. Error & Z-value & Variances & Std. Error \\
\hline \multicolumn{4}{|l|}{ TTQ } & 1,185 & 0,134 \\
\hline TGQ & 1.102 & 0.100 & 11.049 & & \\
\hline TSQ & 0.888 & 0.089 & 9.926 & & \\
\hline TAQ & 1.004 & 0.097 & 10.312 & & \\
\hline \multicolumn{4}{|l|}{ TGQ } & 1.320 & 0.120 \\
\hline TSQ & 0.977 & 0.091 & 10.791 & & \\
\hline TAQ & 1.097 & 0.098 & 11.214 & & \\
\hline \multicolumn{4}{|l|}{ TSQ } & 1.222 & 0.124 \\
\hline TAQ & 1.008 & 0.095 & 10.604 & 1.386 & 0.136 \\
\hline
\end{tabular}


In the next step, we proceeded to apply the refined criteria according to O'Hair (2006) and Byrne (2001), the standardized regression weights (weighting factors) should reach values preferably from $0.7 \mathrm{up}$. In addition, we looked at the results of the individual variability reliability test and excluded the variables with the lowest values from the KMOS test from the model. Thus, we achieved an optimized model with the parameter values that can be seen in the table 8 .

Table 8. Overview of CFA results for WQ after first modification

\begin{tabular}{|c|c|c|c|}
\hline $\begin{array}{c}\chi^{2} \\
\text { (chi square) }\end{array}$ & $\begin{array}{c}\text { df } \\
\text { (degrees of freedom) }\end{array}$ & $\begin{array}{c}\text { CFI } \\
\text { (comparative fit index) }\end{array}$ & $\begin{array}{c}\text { RMSEA } \\
\text { (Root Mean Square Error of } \\
\text { Approximation) }\end{array}$ \\
\hline 629.989 & 183 & 0.947 & 0.073 \\
\hline
\end{tabular}

Source: own elaboration

The next step was to optimize the model based on the variation values of each variable. We removed variables with lower than average values from the model, and we did this process more than once to optimize the model, resulting in a model with the values shown in the table 9.

Table 9. Overview of CFA results for the WQ factor after the second modification

\begin{tabular}{|c|c|c|c|}
\hline $\begin{array}{c}\chi^{2} \\
\text { (chi square) }\end{array}$ & $\begin{array}{c}\text { df } \\
\text { (degrees of freedom) }\end{array}$ & $\begin{array}{c}\text { CFI } \\
\text { (comparative fit index) }\end{array}$ & $\begin{array}{c}\text { RMSEA } \\
\text { (Root Mean Square Error of } \\
\text { Approximation) }\end{array}$ \\
\hline 150.151 & 48 & 0.971 & 0.068 \\
\hline
\end{tabular}

Source: own elaboration

In the last step, because of the low covariance values for the variables of the total content quality factor, we decided to remove this factor from the web quality construct. The result is the model with the values shown in the tables 10 and 11 below.

Table 10. Overview of CFA results for the WQ factor after the third modification

\begin{tabular}{|c|c|c|c|}
\hline $\begin{array}{c}\chi^{2} \\
\text { (chi square) }\end{array}$ & $\begin{array}{c}\text { df } \\
\text { (degrees of freedom) }\end{array}$ & $\begin{array}{c}\text { CFI } \\
\text { (comparative fit index) }\end{array}$ & $\begin{array}{c}\text { RMSEA } \\
\text { (Root Mean Square Error of } \\
\text { Approximation) }\end{array}$ \\
\hline 73.98 & 24 & 0.978 & 0.068 \\
\hline
\end{tabular}

Table 11. CFA for factor WQ - Overview of results of covariance and variance values (variance)

\begin{tabular}{|c|c|c|c|c|c|}
\hline & Estimate & Std. Error & Z-value & Variances & Std. Error \\
\hline \multicolumn{4}{|l|}{ TTQ } & 1.155 & 0.142 \\
\hline TSQ & 0.959 & 0.098 & 9.781 & & \\
\hline TAQ & 1.011 & 0.102 & 9.869 & & \\
\hline \multicolumn{4}{|l|}{ TSQ } & 1.222 & 0.128 \\
\hline TAQ & 1.014 & 0.098 & 10.333 & 1.330 & 0.138 \\
\hline
\end{tabular}

The results suggest that the website quality factor can be understood as a multidimensional construct, consisting of factors of technical quality, quality of special content, and quality of website design. The resulting, optimized model represents a website quality factor. The next step in our analysis will be the implementation of this model into the UTAUT structure of the technology acceptance model followed by the factor relationship testing. 
ISSN 2345-0282 (online) http://jssidoi.org/jesi/ 2021 Volume 9 Number 1 (September) http://doi.org/10.9770/jesi.2021.9.1(34)

\section{Incorporating the construct into the UTAUT research model}

We incorporated the CFA model from the previous part of the research into the SEM calculations, using the technical quality, the quality of the special content, and the quality of the website. All values of these factors point to comparable numbers, the highest values are seen in technical quality. In the first evaluation column we find the value labeled Std.lv, which represents the standardized latent variables. In the next column we find the values of Std.all, which represent both standardized latent and observed variables. These values are often referred to as a complete standardized solution. The tables provide an overview of factor values and reliability expressed through Cronbach alpha and Kaiser-Meyer-Olkin statistics (KMOS). The basic model after calculation reaches the values shown in the table 12 .

Table 12. SEM for WQ - Overview of results of latent variables

\begin{tabular}{|c|c|c|c|c|c|}
\hline & Estimate & Std. Error & Z-value & Std. Iv & Std. all \\
\hline \multicolumn{6}{|c|}{ WQ - website quality } \\
\hline TQ & 1 & & & 0.920 & 0.920 \\
\hline SQ & 0.987 & 0.078 & 12.645 & 0.880 & 0.880 \\
\hline AQ & 1.047 & 0.082 & 12.763 & 0.895 & 0.895 \\
\hline
\end{tabular}

Source: own elaboration

The expected performance factor recorded the highest figures on issues related to the speed and efficiency of banking tasks. Items regarding the impact of electronic banking on improving the quality of banking services and improving the respondent's performance in performing his / her banking tasks were the lowest (table 13).

Table 13. SEM for PE - Overview of results of latent variables

\begin{tabular}{|c|c|c|c|c|c|c|}
\hline \multicolumn{2}{|c|}{ Estimate } & Std. Error & Z-value & Std. Iv & Std. all & KMOS \\
\hline TPE -Expected performance & \multicolumn{3}{|c|}{0} & 1.247 & 0.867 & 0.89 \\
\hline PE 1 & 1 & & & 1.283 & 0.924 & 0.81 \\
\hline PE 2 & 1.029 & 0.036 & 28.385 & 1.199 & 0.915 & 0.84 \\
\hline PE 3 & 0.961 & 0.035 & 27.849 & 0.940 & 0.694 & 0.91 \\
\hline PE 4 & 0.754 & 0.043 & 17.337 & 1.009 & 0.710 & 0.92 \\
\hline
\end{tabular}

Source: own elaboration

\section{Structural model and hypothesis testing}

After a detailed analysis of partial results, within the methods of calculation of the factor analysis, we proceeded to evaluate our research hypotheses and to observe the regression relationships between the individual variables. Detailed statistical values of the model can be found in the individual tables, which show the calculation coefficients for both methods of factor analysis calculation. The factor quality of website has a positive and statistically significant impact on the expected performance of internet banking. For the purposes of this research, we did not explicitly define null hypotheses in evaluating research hypotheses, which represent a generally known relationship to the formulated alternative hypothesis that expresses the existence of a difference. In each hypothesis we observed the influence of the independent variable on the dependent variable. With regard to the evaluation of the hypotheses, estimation methods are indicated in the table, with coefficients always corresponding to the given method. Given the nature of the research, the structural model is drawn up uniformly using the ML estimation method (see tables 14 and 15). 


\section{ENTREPRENEURSHIP AND SUSTAINABILITY ISSUES}

ISSN 2345-0282 (online) http://jssidoi.org/jesi/ 2021 Volume 9 Number 1 (September) http://doi.org/10.9770/jesi.2021.9.1(34)

Table 14. SEM in ML estimation - Overview of structural regression model results

\begin{tabular}{|c|c|c|c|c|c|c|}
\hline & Estimate & Std. Error & Z-value & $\mathbf{p}(>|\mathbf{z}|)$ & Std.lv & Std.al \\
\hline \multicolumn{7}{|c|}{$\begin{array}{l}\text { FREQ } \\
\end{array}$} \\
\hline TWQ & -0.072 & 0.089 & -0.804 & 0.421 & -0.070 & -0.037 \\
\hline \multicolumn{7}{|l|}{ TPE } \\
\hline TWQ & 0.109 & 0.051 & 2.136 & 0.033 & 0.088 & 0.088 \\
\hline
\end{tabular}

Source: own elaboration

Table 15. Overview of statistical evaluation of research hypotheses

\begin{tabular}{|l|l|c|c|c|c|c|c|}
\hline & \multicolumn{1}{|c|}{ Path } & Coefficient & S.E. & $\mathbf{t}(\mathbf{Z})$ & $\mathbf{p}$ & Result & Estimator \\
\hline H1 & TWQ>FREQ & -0.072 & 0.089 & $-0,804$ & & Accept & ML \\
\hline H2 & TWQ>TPE & 0.109 & 0.051 & 2.136 & $* *$ & Support & ML \\
\hline
\end{tabular}

Source: own elaboration

H1. Website quality has a significant impact on the use of online banking.

The hypothesis addresses the significance of the impact of the quality of the website on the actual use of the internet banking by the respondent. We found that the factors in question have statistically insignificant influence on each other. Thus, we reject the hypothesis. Values were achieved based on ML estimation methods.

H2. Website quality has a significant impact on expected performance.

The second hypothesis addressed the impact of the website quality factor on the expected performance in relation to e-banking in terms of users. The result of the investigation is a positive and statistically significant effect at $p$ $<0.01$ and a coefficient of 0.120 . Thus, we support the hypothesis. Values were achieved based on ML estimation methods.

\section{Discussion}

Testing and validating the perception of the quality of the website as a multi-dimensional construct based on the confirmatory factor analysis produced specifics that represent the quality of each of the four dimensions. In modifying the model, we chose to use three items for each dimension to achieve better analytical output, and in the next step we excluded the overall web content quality construct from the model, thus achieving the good model indicated. The quality of the website has proven to be best represented as a multi-dimensional structure more than a uni-dimensional construct, as shown by previous research in this area (Dickinger \& Stangl, 2013). Elements of the website quality that respondents have identified as very important include the security of financial transactions, a number of interactive features, and load speed (technical quality). For the quality aspects of the website's special content, these were the corresponding contact information, detailed information on the bank's products and services, and information regarding customer policy. Among the most important aspects of the website's design, respondents identified the attractiveness of the design, the suitability of colors and the use of appropriate multimedia content.

The multidimensional website quality factor in our research replaces the original attenuating circumstances in the research by Venkatesh, Morris, Davis \& Davis (2003) and its UTAUT models. The results of our research show the indirect effect of perceived quality of website design on the use of internet banking through the expected performance factor. These results support the results of another research in this area, where the effect of the web design quality construct on the use of internet banking indicated a significant impact of this factor through the expected performance factor (Al-Qeisi, 2014). Based on the results of our research, we can point to the issue of 


\section{ENTREPRENEURSHIP AND SUSTAINABILITY ISSUES}

ISSN 2345-0282 (online) http://jssidoi.org/jesi/ 2021 Volume 9 Number 1 (September)

http://doi.org/10.9770/jesi.2021.9.1(34)

the mobile banking factor, which may reduce the direct significant impact of the web design quality factor on the use of electronic banking.

\section{Conclusion}

In general, the results of our research show that the perceived quality of the website is a multi-dimensional concept. The quality of the website has an indirect impact on the behavior of the user, which is expressed by the frequency of using internet banking. This indirect effect is mediated by the expected performance factor.

Banking institutions, as well as other companies and individuals, gain many benefits from well-designed websites, effective communication on social networks, and also by exploiting the potential of mobile marketing. The presented work show the current state of knowledge in the field of research into the use and acceptance of technology, applying this issue to the model of the use of electronic banking technology.

\section{References}

Ahmed, R. R., Romeika, G., Kauliene, R., Streimikis, J., \& Dapkus, R. (2020). ES-QUAL model and customer satisfaction in online banking: evidence from multivariate analysis techniques. Oeconomia Copernicana, 11(1), 59-93. https://doi.org/10.24136/oc.2020.003

Aladwani, A. M., \& Palvia, P. C. (2002). Developing and validating an instrument for measuring user-perceived web quality. Information \& management, 39(6), 467-476.

Aladwani, A. M. (2006). An empirical test of the link between web site quality and forward enterprise integration with web consumers. Business Process Management Journal. https://www.emerald.com/insight/content/doi/10.1108/14637150610657521/full/html

Al-Qeisi, K., Dennis, C., Alamanos, E., \& Jayawardhena, C. (2014). Website design quality and usage behavior: Unified Theory of Acceptance and Use of Technology. Journal of Business Research, 67(11), 2282-2290.

Andrews, L., \& Bianchi, C. (2013): Consumer internet purchasing behavior in Chile. Journal of Business Research, 66(1), 1791-1799.

Bauer, H. H., Falk, T., \& Hammerschmidt, M. (2006). eTransQual: A transaction process-based approach for capturing service quality in online shopping. Journal of Business Research, 59(7), 866-875.

Bernardelli, M., Korzeb, Z., \& Niedziółka, P. (2021). The banking sector as the absorber of the COVID-19 crisis? Economic consequences: perception of WSE investors. Oeconomia Copernicana, 12(2), 335-374. https://doi.org/10.24136/oc.2021.012

Byrne, B. M. (2001). Structural equation modeling with AMOS, EQS, and LISREL: Comparative approaches to testing for the factorial validity of a measuring instrument. International journal of testing, 1(1), 55-86.

Cortiñas, M., Chocarro, R., \& Villanueva, M. L. (2010). Understanding multi-channel banking customers. Journal of Business Research, 63(11), 1215-1221.

Cunningham, L. F., Gerlach, J. H., Harper, M. D., \& Young, C. E. (2005). Perceived risk and the consumer buying process: internet airline reservations. International Journal of Service Industry Management, 16(4), 357-372. https://doi.org/10.1108/09564230510614004

Dennis, C., Merrilees, B., Jayawardhena, C., \& Wright, L. T. (2009). An empirical investigation into e-shopping excitement: antecedents and effects. European Journal of Marketing, 43(9/10), 1121-1139.

Dickinger, A., \& Stangl, B. (2013). Website performance and behavioral consequences: A formative measurement approach, In: Journal of Business Research, 66(6), 771-777.

Featherman, M. S., \& Pavlou, P. A. (2003). Predicting e-services adoption: a perceived risk facets perspective, In: International journal of human-computer studies, 59(4), 451-474. 


\section{ENTREPRENEURSHIP AND SUSTAINABILITY ISSUES}

ISSN 2345-0282 (online) http://jssidoi.org/jesi/

2021 Volume 9 Number 1 (September)

http://doi.org/10.9770/jesi.2021.9.1(34)

Floh, A., Zauner, A., Koller, M., \& Rusch, T. (2014). Customer segmentation using unobserved heterogeneity in the perceived-valueloyalty-intentions link. Journal of Business Research, 67(5), 974-982.

Gorączkowska, J. (2020). Enterprise innovation in technology incubators and university business incubators in the context of Polish industry. Oeconomia Copernicana, 11(4), 799-817. https://doi.org/10.24136/oc.2020.032

Gounaris, S., Koritos, C., \& Vassilikopoulou, K. (2010). Person-place congruency in the Internet Banking context. Journal of Business Research, 63(9-10), 943-949.

Korzeb, Z., \& Niedziółka, P. (2020). Resistance of commercial banks to the crisis caused by the COVID-19 pandemic: the case of Poland. Equilibrium. Quarterly Journal of Economics and Economic Policy, 15(2), 205-234. https://doi.org/10.24136/eq.2020.010

Kwon, O. B., Kim, C. R., \& Lee, E. J. (2002). Impact of website information design factors on consumer ratings of web-based auction sites. Behaviour \& information technology, 21(6), 387-402.

Lee, M. C. (2009). Factors influencing the adoption of internet banking: An integration of TAM and TPB with perceived risk and perceived benefit. Electronic commerce research and applications, 8(3), 130-141.

Liao, Z., \& Cheung, M. T. (2002). Internet-based e-banking and consumer attitudes: an empirical study. Information \& management, 39(4), 283-295.

Małkowska, A., Urbaniec, M., \& Kosała, M. (2021). The impact of digital transformation on European countries: insights from a comparative analysis. Equilibrium. Quarterly Journal of Economics and Economic Policy, 16(2), 325-355. https://doi.org/10.24136/eq.2021.012

Martins, C., Oliveira, T., \& Popovič, A. (2014). Understanding the Internet banking adoption: A unified theory of acceptance and use of technology and perceived risk application. International Journal of Information Management, 34(1), 1-13.

Moss, G., Gunn, R., \& Heller, J. (2006). Some men like it black, some women like it pink: consumer implications of differences in male and female website design. Journal of Consumer Behaviour, 5(4), 328-341.

Streimikiene, D., \& Ahmed, R. R. (2021). The integration of corporate social responsibility and marketing concepts as a business strategy: evidence from SEM-based multivariate and Toda-Yamamoto causality models. Oeconomia Copernicana, 12(1), 125-157. https://doi.org/10.24136/oc.2021.006

Tan, M., \& Teo, T. S. (2000). Factors influencing the adoption of Internet banking. Journal of the Association for information Systems, $1(1), 5$.

Venkatesh, V., Brown, S. A., Maruping, L. M., \& Bala, H. (2008). Predicting different conceptualizations of system use: the competing roles of behavioral intention, facilitating conditions, and behavioral expectation. MIS quarterly, 483-502.

Venkatesh, V., Morris, M. G., Davis, G. B., \& Davis, F. D. (2003). User acceptance of information technology: Toward a unified view. MIS quarterly, 425-478.

Vila, N., \& Kuster, I. (2011). Consumer feelings and behaviours towards well designed websites. Information \& Management, 48(4-5), $166-177$.

Thongpapanl, N., \& Ashraf, A. R. (2011). Enhancing online performance through website content and personalization. Journal of Computer Information Systems, 52(1), 3-13.

Toufaily, E., Ricard, L., \& Perrien, J. (2013): Customer loyalty to a commercial website: Descriptive meta-analysis of the empirical literature and proposal of an integrative model. Journal of Business Research, 66(9), 1436-1447.

Xue, M., Hitt, L. M., \& Chen, P. Y. (2011). Determinants and outcomes of internet banking adoption. Management Science, 57(2), 291307.

Yousafzai, S., \& Yani-de-Soriano, M. (2012). Understanding customer-specific factors underpinning internet banking adoption. International Journal of Bank Marketing, 30(1), 60-81. 


\section{ENTREPRENEURSHIP AND SUSTAINABILITY ISSUES}

ISSN 2345-0282 (online) http://jssidoi.org/jesi/ 2021 Volume 9 Number 1 (September)

http://doi.org/10.9770/jesi.2021.9.1(34)

\section{Acknowledgements}

This article is one of the partial outputs under the scientific research grant VEGA 1/0694/20 - Relational marketing research - the perception of e-commerce aspects and its impact on purchasing behaviour and consumer preferences and VEGA 1/0609/19 - Research on the development of electronic and mobile commerce in the aspect of the impact of modern technologies and mobile communication platforms on consumer behaviour and consumer preferences and 1/0807/19 - Research on the determinants of trading behavior and marketing effects in the area of neuromarketing and the relation to neuro-linguistic programming

Radovan BACIK has been working as a lecturer at the Department of Marketing and International Trade of the University of Prešov since 2009. In his research activities, he is focusing on the issues of Public relations, Public relations in tourism, marketing of selected areas, strategic marketing, presentation of management and marketing, communication in management, branding and innovation and online marketing.

ORCID ID: https://orcid.org/0000-0002-5780-3838

Beata GAVUROVA (corresponding author) is an expert in finance, financial analysis and financial risk management. She focuses in her research work on issues of measurement and performance management in various sectors, process management and process optimization, strategic and performance benchmarking. Her dominant research area is the development and testing in the management and performance measurement, the evaluation of methodologies and the preparation of an application platform for innovative management and performance measurement with the support of ICT. She led several national projects, has participated in many international projects targeting the innovative applications of ICT in the private and public sector.

ORCID ID: https://orcid.org/0000-0002-0606-879X

Igor FEDORKO focuses his research on the issue of models of unified theory of acceptance and use of technology. He also focuses his publication outputs on the mentioned issues. As a co-investigator, he has collaborated and is collaborating on several successful scientific research projects and grants. ORCID ID: https://orcid.org/0000-0003-1974-7465

Richard FEDORKO has been working as a lecturer at the Department of Marketing and International Trade of the University of Prešov since 2014. In his research activities he is focusing on the issues of online marketing and e-commerce, especially on the fields of online advertising, online reputation, social media, customer support, consumer behaviour and mobile marketing.

ORCID ID: https://orcid.org/0000-0003-3520-1921

Make your research more visible, join the Twitter account of ENTREPRENEURSHIP AND SUSTAINABILITY ISSUES: @Entrepr69728810

Copyright (C) 2021 by author(s) and VsI Entrepreneurship and Sustainability Center

This work is licensed under the Creative Commons Attribution International License (CC BY).

http://creativecommons.org/licenses/by/4.0/

(c) (i) Open Access 